\title{
Blue-Cone Horizontal Cells in the Retinae of Horses and Other Equidae
}

\author{
Daniele Sandmann, ${ }^{1}$ Brian B. Boycott, ${ }^{2}$ and Leo Peichl ${ }^{1}$ \\ ${ }^{1}$ Max Planck Institut für Hirnforschung, D-60528 Frankfurt, Germany and 2Department of Anatomy and Cell Biology, \\ United Medical and Dental School (Guy's Campus), London SE1 9RT, United Kingdom
}

The morphology of horizontal cells chiefly of the horse, but also of asses, mules, and a zebra, has been examined by Lucifer yellow injections into lightly fixed retinae and by immunocytochemistry. In common with other mammals, equids have a B-type horizontal cell, i.e., a cell with dendrites synapsing with cones and possessing a single axon synapsing with rods. Most mammalian retinae have a further type of horizontal cell, the A-type, also synapsing with cones but without an axon. The second type of horizontal cell in equids also has no axon; otherwise, it is most unusual. Compared with other mammalian A-type cells, it has a very large dendritic field, both absolutely and relative to the dendritic fields of B-type cells. The dendrites are fine and sparsely branching. Their most striking feature is that they bear a low density of irregularly spaced synaptic terminal aggregates, suggesting their cone contacts are selective. Immunolabeling of $\mathrm{S}$ (blue)-cones in horse retina showed that they comprise, depending on retinal location, $10-25 \%$ of the cone population. For a single horse A-type cell, it is shown that 44 of its 45 terminal aggregates are congruent with the pedicles of S-cones. Immunostaining with a calbindin antibody demonstrated that each type of horizontal cell forms an independent regular mosaic. The density ratio of B- to A-type cells varied between 5 and 10 . This is the first demonstration in a mammalian retina of a horizontal cell type with a direct input exclusively from S-cones.

Key words: horizontal cells; mammalian retina; horse retina; retinal organization; blue-cone photoreceptors; chromatic specificity; Equidae
Horizontal cells are retinal interneurons modulating the synaptic transmission between photoreceptor and bipolar cells. It is believed that they are anatomically and functionally rather similar throughout mammals. One of the most important comparative anatomical descriptions of mammalian horizontal cells is that by Ramón y Cajal (1893). He concluded that the basic components of all mammalian retinae are virtually identical and, in particular, that there are two types of horizontal cells. It is now established for several mammalian species that there is an axonless horizontal cell, called the A-type, synapsing with all kinds of cones, and a B-type, synapsing with the same cones and having a single axon ending in the rod terminals (for review, see Gallego, 1986; Boycott et al., 1987; Sandmann ct al., 1996). But more recent work is beginning to show variants of this pattern, at least between mammalian orders. For example, primates have $\mathrm{H} 1$ horizontal cells readily comparable to the general mammalian B-type, but the second (H2) type also has an axonal process (Kolb et al., 1980; Boycott et al., 1987). Both types, although possessing mixed cone inputs, have a component of cone selectivity (Dacey et al., 1996; Goodchild et al., 1996). Some murid retinae only have the axonbearing B-type cells; they lack the axonless A-type cells (Peichl and González-Soriano, 1994). Further examples are given in Sandmann et al. (1996). During a reinvestigation of the retinae of species central to Ramón y Cajal (1893) claims (primarily based

\footnotetext{
Received Nov. 6, 1995; revised Feb. 27, 1996; accepted Feb. 29, 1996.

We thank C. W. Heizmann, J. Nathans, and A. Szél for providing antibodies; Dr. Grootenhuis of the Game Ranching Ltd., Kenya, J. González-Soriano, S. Mayayo, and B. Pflug for their help in obtaining the eyes; and U. Grünert and A. Goodchild for helpful comments on this manuscript. The skilled technical assistance of $\mathrm{H}$. Ahmed also is gratefully acknowledged.

Correspondence should be addressed to Daniele Sandmann, Max Planck Institut für Hirnforschung, Deutschordenstrasse 46, D-60528 Frankfurt, Germany. Copyright (C) 1996 Society for Neuroscience $0270-6474 / 96 / 163381-16 \$ 05.00 / 0$
}

on the retinae of ox, sheep, pig, and horse), the horizontal cells of artiodactyls have been found to conform broadly with Ramón y Cajal descriptions (Sandmann et al., 1996), but those of equids have proved unexpectedly different and are reported here.

As with other mammals, the horse retina contains B-type horizontal cells. Their description in the early literature was fragmentary (Rivolta, 1871; Golgi and Manfredi, 1872; Kallius, 1894; Vogt, 1902). There appears to have been no further work since the fuller descriptions of Kolmer (1936). Here we describe the B-type cell in more detail and, in addition, an axonless horizontal cell that we show to be selectively connected to $\mathrm{S}$ (blue)-cones.

Some of the results have been published as an abstract (Peichl et al., 1995).

\section{MATERIALS AND METHODS}

The eyes of 16 adult domestic horses (Equus caballus) of either sex were obtained from a local slaughterhouse; those of five domestic asses (Equus asinus) and three mules and/or hinnies came from a slaughterhouse in Madrid, Spain. The eyes of one Grevy's zebra (Equus grevy) were obtained from a Kenyan wildlife park during culling. All the eyes were enucleated within 15 min post mortem and opened by an encircling cut some millimeters behind the corneal edge. The vitreous was completely removed before fixation from those retinae to be used for immunocytochemistry, but only partly removed, to avoid mechanical stress on the unfixed retina, when they were to be dye-injected. The posterior eye cup was immersion-fixed in $4 \%$ paraformaldehyde (PA) in $0.1 \mathrm{M}$ phosphate

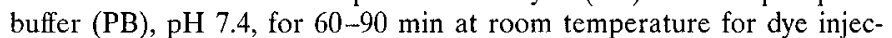
tions. For immunocytochemistry, time in the same fixative was extended to 2-4 hr. All cyc cups were transferred to PB containing $0.05 \%$ sodium azide for transport and storage.

\section{Intracellular injection of Lucifer yellow}

Remaining vitreous was carefully removed with scissors at this stage. Pieces of peripheral retina were usually used because dye injections are technically more successful there than in the thicker central regions; the approach was from the vitreal side. Single horizontal cells were intracel- 
lularly injected with the fluorescent dye Lucifer yellow (LY; Sigma, St. Louis, MO) based on the original protocol of Tauchi and Masland (1984). Details of the injection procedure are given in Peichl and GonzálezSoriano $(1993,1994)$. None of the conventional techniques for prelabeling horizontal cell somata were successful; therefore, in advancing the micropipette through the inner nuclear layer, we relied on chance for impaling horizontal cells. The dendrites of an impaled horizontal cell were usually completely filled using a constant negative current of 1-3 nA for 10-25 min. More than 300 horizontal cells of horse and several dozen of ass and mule were filled. Injected retinae were washed in PB overnight at $4{ }^{\circ} \mathrm{C}$, post-fixed in $4 \% \mathrm{PA}$ for $1 \mathrm{hr}$, and again washed in $\mathrm{PB}$. They were mounted on glass slides in a mixture of glycerol ( 9 parts) and PBS (1 part) with $2.5 \%$ potassium iodide added, coverslipped, and observed vitreal side up. Focal series of LY-filled horizontal cells were photographed, and drawings of the cells were made by projection of the negatives. Dimensional data were not corrected for shrinkage. This is variable in glycerol and depends on the size of the mounted pieces; it usually amounts to $\sim 10 \%$ in area. After photography, some retinal pieces were removed from the slide, washed in $\mathrm{PB}$, and processed for immunocytochemistry.

\section{Application of DiI}

The lipophilic carbocyanine dye Dil (D-282; Molecular Probes, Eugene, $\mathrm{OR}$ ) is a tracer that is transported in fixed membranes and reveals single-cell morphologies. For DiI application, the fixation time in 4\% PA was extended to a minimum of 1 week. Fixed retinal pieces were flattened on a black cellulose nitratc filter. Small crystals of Dil were placed at widely spaced locations on the surface with a micropipette and pushed gently into the retina. The tissue was returned to the fixative at $4^{\circ} \mathrm{C}$ and regularly monitored. After a few days, clusters of horizontal cells (as well as many other neuron types) were labeled near the site of crystal application. With periods up to several weeks, DiI moved along the axons to expose more isolated horizontal cells. For observation and photography, DiI-labeled tissue was coverslipped in PB.

\section{Immunocytochemistry}

Immunocytochemistry was performed on both unsectioned retinal pieces and horizontal sections (i.e., sections parallel to the retinal layers). Cryoprotection was by successive immersion in 10,20 , and $30 \%$ sucrose (overnight) in PB. Whole pieces were repeatedly shock-frozen and thawed to improve antibody penetration. For horizontal sections, pieces were flat-mounted on a block of frozen embedding medium, and 40- to $60-\mu \mathrm{m}$-thick sections were cut on a freezing microtome. Both sectioned and unsectioned tissue was processed free-floating.

Antibodies. To reveal horizontal cell populations, we used a rabbit antiserum against rat calbindin (CaBP D-28K; kindly provided by Dr. C. W. Heizmann) (Pinol et al., 1990) at a dilution of 1:2000 and a mouse monoclonal antibody against the neurofilament triplet protein NF-H (antibody N 52, dilution 1:500; Sigma). Rabbit antisera JH 455 (dilution 1:5000) against the human blue-cone pigment and $\mathrm{JH} 492$ (dilution 1:2000) against the human red- and green-cone pigments (kindly provided by Dr. J. Nathans) (Wang et al., 1992) were used to stain cone types. Double staining was by the additional use of the mouse monoclonal antibody OS-2 (dilution 1:10,000) against blue cones (kindly provided by Dr. A. Szél) (Szél ct al., 1986). Somc LY-fillcd cclls wcrc immunorcacted with a rabbit antiserum against LY (dilution 1:500; Molecular Probes, Eugene, OR) to obtain a stable reaction product. There is evidence that the horse is a dichromat with one short wavelength-sensitive (blue) cone type and one medium-to-long wavelength-sensitive (green/red) cone type (see Discussion). We shall refer to these as S-cones and $\mathrm{M} / \mathrm{L}$-cones, respectively.

Immunostaining. Nonspecific binding sites were blocked by leaving the tissue for $1 \mathrm{hr}$ in PB with $10 \%$ normal goat serum (NGS) and $0.5 \%$ Triton $\mathrm{X}-100$. The tissuc was then placed in the primary antibody solution for 2-3 d. The antibodies were used at the above dilutions in PB containing $3 \%$ NGS, $0.5 \%$ Triton X-100, and $0.05 \%$ sodium azide. Processing was continued overnight in goat anti-rabbit IgG or goat anti-mouse IgG in PB with $3 \%$ NGS and $0.5 \%$ Triton X-100, followed by an overnight period in rabbit peroxidase-antiperoxidase, or mouse peroxidase-antiperoxidase, in the same medium as the secondary antibody. For antibody N52, the avidin-biotin-peroxidase complex method produced better staining. The peroxidase was visualized with diaminobenzidine (DAB) and $\mathrm{H}_{2} \mathrm{O}_{2}$. All steps were performed at room temperature. The reacted tissue was flattened onto slides, semidried for better adhesion, and coverslipped with an aqueous mounting medium. With this mounting procedure, tissue shrinkage was negligible.
Sectioned tissue yielded a more intensive immunoreaction with antibodies against calbindin and neurofilaments. The cone and LY antibodies had to be used on unsectioned tissue because of the need to preserve intact cells. Sometimes the $\mathrm{DAB}$ reaction product was intensified by immersing the reacted tissue in nitro blue tetrazolium and exposing it to intense green light (Vaney, 1992). When S-cones and I Y-filled horizontal cells were simultaneously immunoreacted and visualized with $\mathrm{DAB}$, the appropriate staining solutions were applied as mixtures. Simultaneous visualization of S-cones and $\mathrm{M} / \mathrm{L}$-cones was performed by double immunofluorescence with a fluorescein isothiocyanate (FITC)-coupled secondary antibody for OS-2 and a Texas red-coupled secondary antibody for JH 492. Controls showed no staining when the primary antibodies were omitted.

The density distribution of horse horizontal cells was analyzed in one calbindin immunostained whole retina; representative areas of additional retinae were used for confirmatory data. The regularity of the mosaic of calbindin-stained horizontal cells was examined by a nearest-neighbor analysis (Wässle and Riemann, 1978).

One horse retina, stained with a reduced silver method and used previously in a study of retinal ganglion cells (Peichl et al., 1987), was examined for the neurofibrillar staining of the horizontal cells.

\section{Topography of the horse retina}

The horse retina is primarily avascular (Johnson, 1968; Schnitzer, 1988). When spread flat, it has a diameter of $65-70 \mathrm{~mm}$. The optic nerve head is situated approximately halfway between the geometric center and the inferior margin of the retina, and is slightly temporal of the vertical midline. Approximately $5 \mathrm{~mm}$ superior to the optic nerve head there is a narrow horizontal band of high ganglion cell density extending from temporal to nasal periphery, the visual streak (Hebel, 1976) (see also Fig. $9 C$ ). Near its temporal end, the visual streak contains a central area with the highest ganglion cell density. Immediately outside the visual streak, ganglion cell densities are uniformly low and do not show significant changes with retinal location. A tapetum lucidum is present over most of superior retina. Its inferior boundary at the level of the optic nerve head is sharp and horizontal (Johnson, 1968). These landmarks, present also in ass, mule, and zebra eyes, were used to orient the retinae and define topographic positions within them.

\section{RESULTS}

\section{Morphology of equid B-type horizontal cells}

The dendritic morphology of equid B-type horizontal cells is illustrated in Figure 1. The somata of $\sim 15-20 \mu \mathrm{m}$ diameter are located at the outer margin of the inner nuclear layer. From the soma, 8-10 stout primary dendrites radiate outward, making only a few main branches and tapering toward the periphery of the dendritic field (Figs. 1A,B,4). Beginning at the soma, numerous fine branches arise all along the lengths of the dendrites. Each branch ends in clusters of terminals (terminal aggregates) all arrayed on the same plane in the outer plexiform layer (Figs. $1 B$, 4). This is characteristic of the terminals of mammalian horizontal cells contacting cones (Boycott and Dowling, 1969; Gallego, 1976; Wässle et al., 1978a). Although B-type cell morphology is rather uniform across the equid retina, cells in inferior retina may have relatively finer main dendrites and slightly more irregular dendritic fields (see Fig. 4). The dendritic field diameters of peripheral B-type cells are between 170 and $220 \mu \mathrm{m}$. Each cell has between 100 and 120 terminal aggregates and, therefore, contacts 100-120 cones. Near the visual streak, dendritic field diameters as small as $95 \mu \mathrm{m}$ were observed.

Every B-type horizontal cell has an axon that usually originates as an extension from a primary dendrite (arrow in Fig. $1 A$ ). For a distance of up to $1 \mathrm{~mm}$ from the perimeter of the dendritic field, the axon may have branches ending in terminal aggregates (Fig. $1 A$ ). Like those on the dendrites, these presumably contact cones. The diameter of the axon for the first $0.5-1 \mathrm{~mm}$ from its origin is $2.5-3.5 \mu \mathrm{m}$, and then it gradually tapers to $1 \mu \mathrm{m}$ or less. From LY injections into the somata it was only possible to obtain axonal 

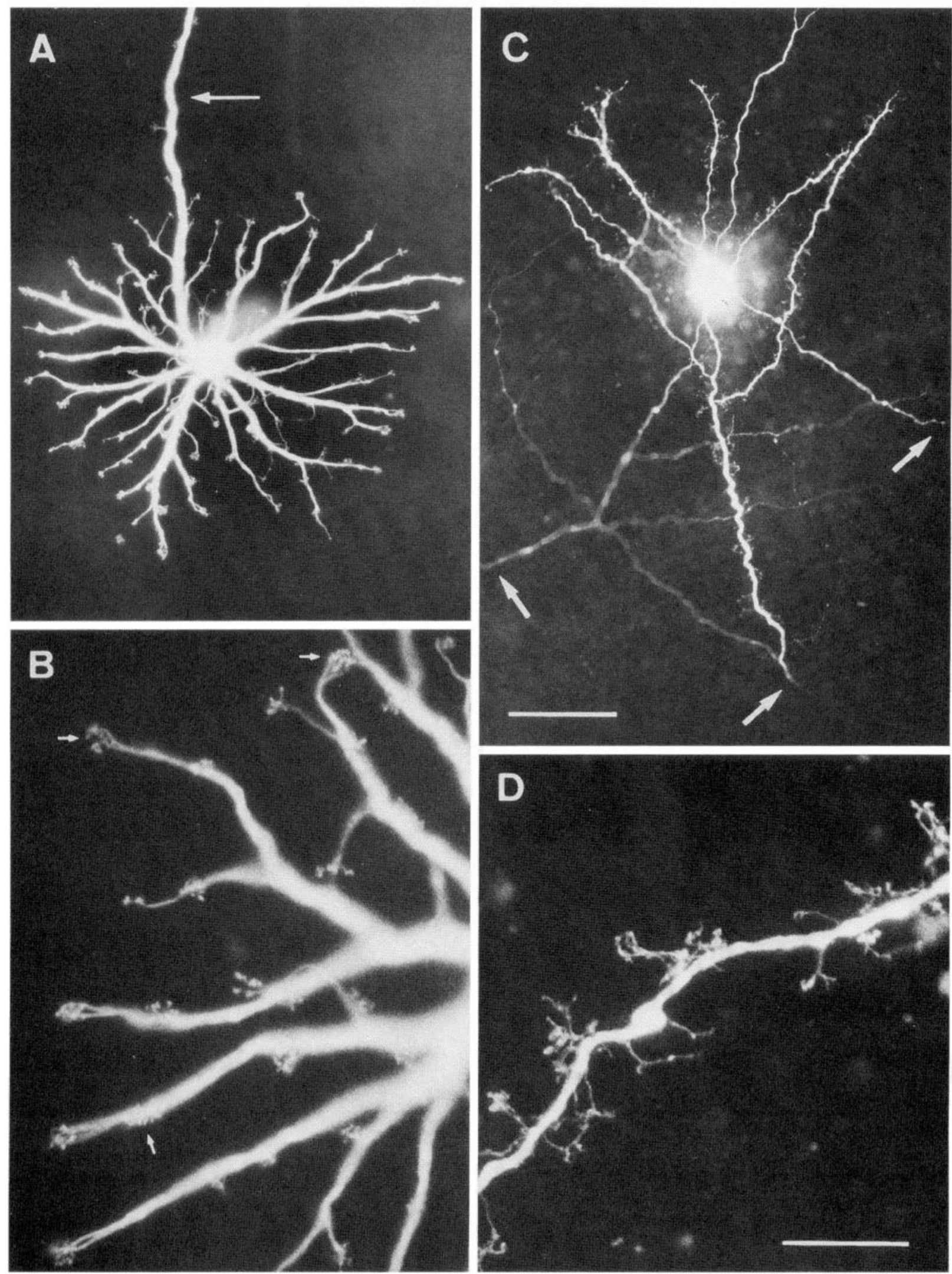

Figure 1. LY-injected B-type horizontal cells in peripheral horse retina. $A$, Dendritic tree in the OPL, the dendrites end in clusters of terminals (terminal aggregates). An arrow marks the axon; the initial part bears a few terminal aggregates. $B$, Higher magnification showing terminal aggregates (three of them marked by arrows); each group is a cluster of the synaptic contacts with one cone. $C$, Three axon terminal systems injected where their processes cross. Arrows indicate where the axon thickens as it branches and begins to bear terminals. $D$, Higher magnification of an axon terminal branch studded with short processes that end in single terminals. Scale bar in $C, 50 \mu \mathrm{m}$ for $A, 100 \mu \mathrm{m}$ for $C$; scale bar in $D, 20 \mu \mathrm{m}$ for $B$ and $D$. 


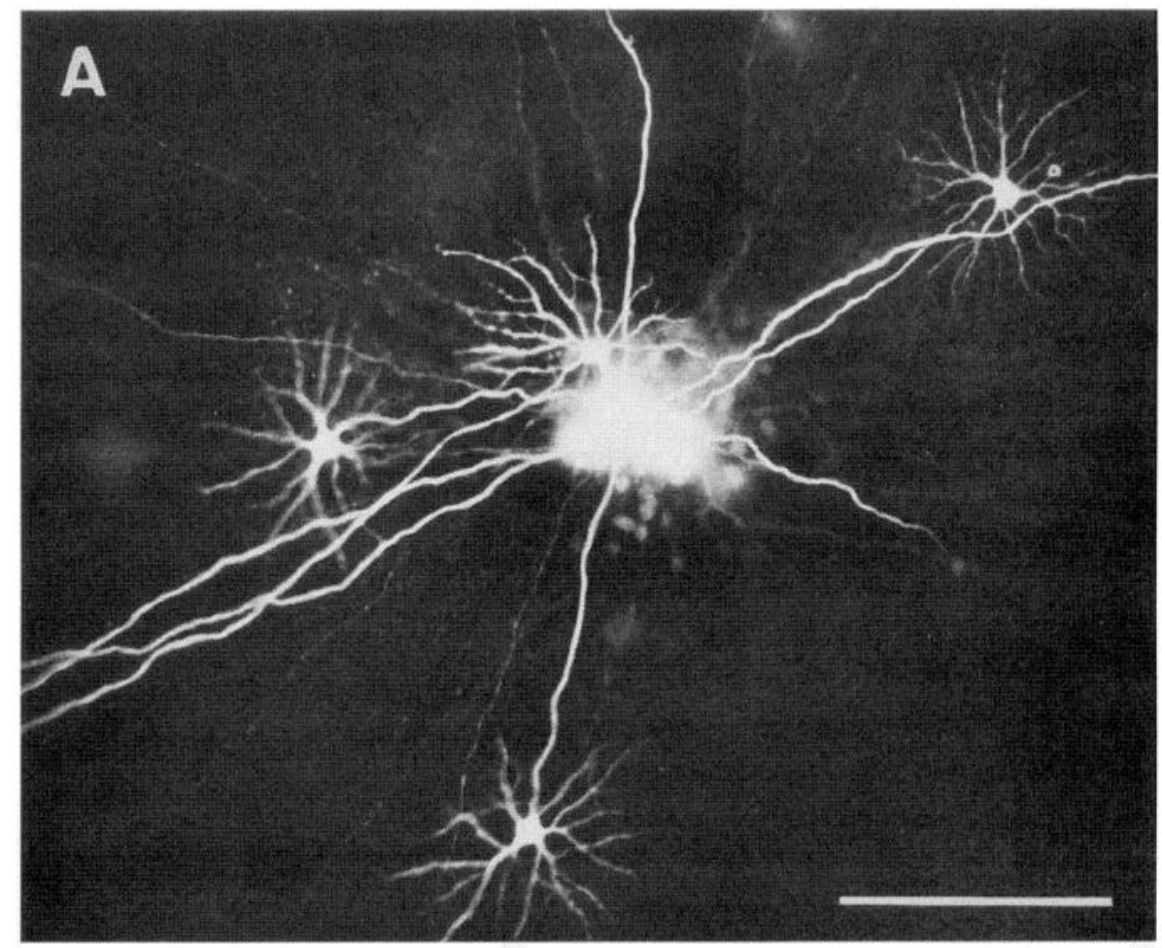

Figure 2. Axonal features of horse B-type cells. $A$, Several straight axons simultaneously filled by a single injection of LY. The axons are of a length that some of the parent cells are outside the field; four cell bodies and dendrites of B-type cells are in view. B, B-type cells labeled through their axons by DiI applied outside the field. All axons are straight, long, and originate from cells with B-type morphology. Scale bars, $100 \mu \mathrm{m}$.

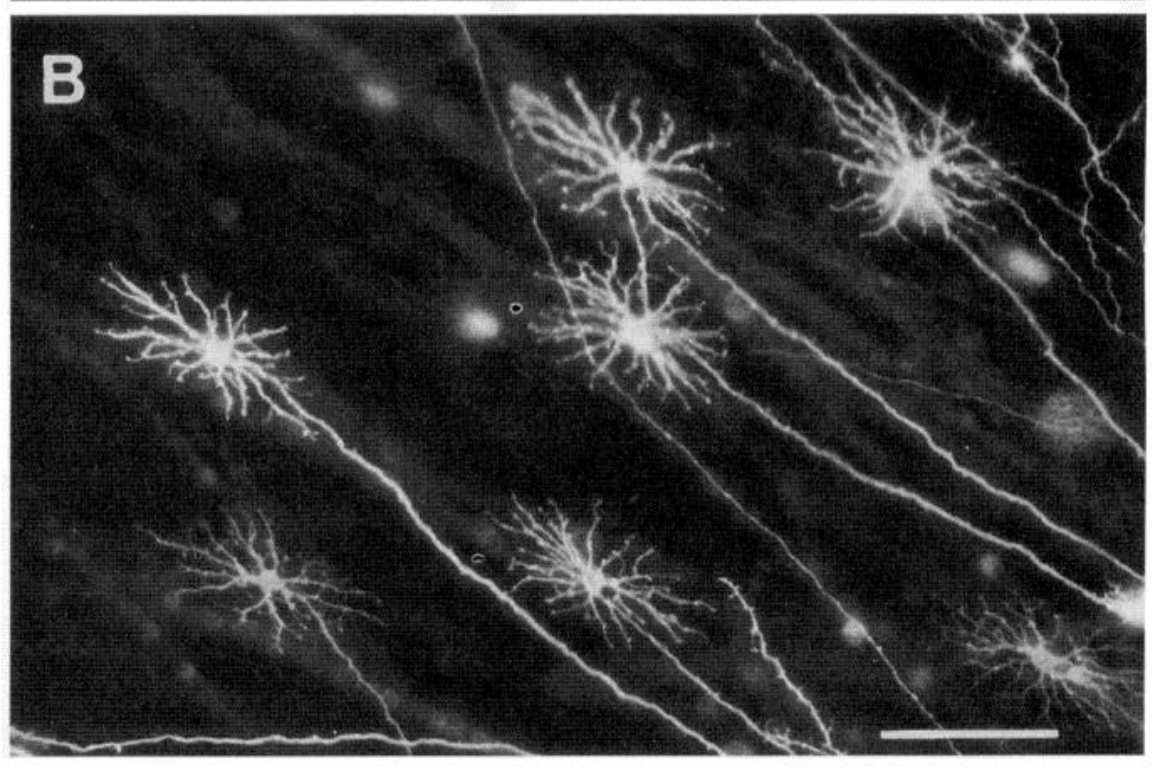

lengths up to $2.5 \mathrm{~mm}$. For this distance, the axons ran straight in the outer plexiform layer; only rarely was there an abrupt change of direction. The axons do not travel in a particular direction relative to the visual streak or optic nerve head; local injections of axons showed them crossing the injection site to and from many different directions (Figs. 1C, 2A). With some filled axons, the parent cell body and dendrites were retrogradely labeled and showed the axons to belong to a cell with B-type morphology (Fig. $2 A$ ). On other occasions, axon terminal arborizations were revealed (Figs. $1 C, 4$ ). B-type cells could never be completely filled from the dendrites to the axon terminal system; there appears to be some obstruction, perhaps the thinning of the middle of the axon. From the above observations, we infer that all axons belong to B-type cells. Furthermore, equid retinae contain no other horizontal cells with (even partially filled) processes that would be compatible with these axons. Because some directly injected axons had lengths of 2-2.5 mm without ending in a soma or axon terminal system, the axons of equid B-type cells must be longer than this. Their considerable length is further demonstrated when the whole population is stained by neurofibrillar methods (see end of Results). From observations in methylene-blue-stained retinae, Kolmer (1936) suggested axonal lengths of several centimeters, but he does not explain how he arrived at this datum in the absence of completely stained cells. The axonal lengths of completely stained B-type horizontal cells in other mammals are 0.7 mm or less [e.g., cat: $0.3-0.5 \mathrm{~mm}$ (Boycott et al., 1978); rabbit: 0.4-0.6 mm (Vaney, 1993); sheep: 0.5-0.7 mm (Sandmann et al., 1996)]; except for several species of monkeys reported as 1.1-2.5 mm (Gallego, 1976; Mariani, 1984a).

Some distance before the axon of a B-type cell ends, there is a gradual increase from a minimal diameter of $<1 \mu \mathrm{m}$ to $2-2.5 \mu \mathrm{m}$. This thickening is the beginning of the axon terminal system and 
it sometimes bears fine terminals (Figs. 1C, 4). In many mammals, the thickened part of the axon branches extensively and forms a high density of finc terminals; the whole is arrayed compactly to cover a circular or oval area (Boycott et al., 1978; Kolb and Normann, 1982; Peichl and González-Soriano, 1994; Sandmann et al., 1996). In detail, the equid axon terminal system is different. It covers an unusually elongated area, and there is a large spacing between the thicker branches, which tend to run straight (Figs. $1 C$, 4). The finer branches extending from these go toward the photoreceptors; because they end at varying levels (Fig. $1 D$ ), it can be concluded that, as in other mammals, they contact rods (Ramón y Cajal, 1893). Equid axon terminal systems are large. We had no means to estimate the completeness of filling with LY; therefore, their dimensions were not measured.

LY injections of ass and mule retinae (not illustrated except for Fig. 6) revealed B-type horizontal cells indistinguishable from those of the horse. Dil staining confirmed the LY observations in horse (see Fig. $2 B$ ), ass, and mule. It too did not completely reveal B-type axons. But when retrograde labeling occurred, the parent cells always had a B-type dendritic morphology, thus confirming that the horizontal cell axons in the equid retina are unique to the B-type cells.

In one ass retina, 8 of $20 \mathrm{LY}$-injected B-type cells had a process that descended into the inner plexiform layer, where it branched. This may have been a feature of the individual animal, because we did not observe descending processes on horizontal cells in another injected ass retina or in any of the horse and mule retinae.

\section{Morphology of equid A-type horizontal cells}

The second type of equid horizontal cell revealed in the present study (Fig. $3 A$ ) is sufficiently different from previously described A-type cells for us to have taken particular care to establish that there is probably not a third type of horizontal cell. We shall show that, unlike most known A-type cells, those in the retinae of equids selectively innervate S-cones and, in the absence of a further kind of horizontal cell, that most of the cones in equid retinae are innervated by only one kind of horizontal cell.

A-type cell somata are positioned at the border between the inner nuclear and outer plexiform layers. This, their large dendritic fields, and the absence of a process descending to the inner retina, indicate that they are horizontal cells. Their somata are $-10-12 \mu \mathrm{m}$ in diameter and tend to be triangular. Between three and six very thin primary dendrites arise from each cell body; these branch occasionally at widely spaced intervals (Figs. $3 A$, 4). At irregular intervals along all the dendrites there are very fine short processes, which ascend to the photoreceptor terminals. Here they end in aggregates of terminals at the plane of the cone pedicles (Fig. 3B-D). On B-type cells, the aggregates correspond in area to the dimensions of the cone pedicle bases (Figs. $1 B, 6$ ). On A-type cells, they are smaller, and it appears that there are, on average, fewer terminals per aggregate than for B-type cells (Figs. $3 B-D, 4)$. A most distinctive feature is that the spacing between terminal aggregates is much wider and less regular than on the B-type cells. There is no axon.

Our sample of LY-injected horse A-type cells is limited to 6 compared with $>300$ of the B-type. A few clearly understained A-type cells were seen in a DiI-labeled ass retina. They could not be analyzed in detail because they were embedded in a plexus of other stained cells, but they served to demonstrate the peculiar morphology of horse A-type cells in another equid. The low yield and incomplete filling is probably attributable to the small somata; the low population density; and the fineness, length, and sparsity of the dendrites. These properties reduce the probability of impaling a cell as well as the amount of dye diffusing along the dendrites. The most completely filled A-type cells had dendritic field diameters between 400 and $600 \mu \mathrm{m}$ and between 40 and 60 terminal aggregates. This compares with $\sim 100$ terminal aggregates on the much smaller B-type cells. Because even the best injected A-type cells had one or more incompletely filled dendrites, their dendritic fields may be even larger than our present estimates. Whatever the completeness of filling, the terminal aggregates on the dendrites were always few and irregularly arrayed. Thus, there is a prima facie case that equid A-type cells synapse with a subset of the cone population within their dendritic fields.

\section{Cone connections}

For an assessment of cone types, tissue was reacted with the antiserum $\mathrm{JH} 492$ specific for the $\mathrm{M} / \mathrm{L}$ (green/red)-cone pigment and the antiserum $\mathrm{JH} 455$ specific for the S (blue)-cone pigment. Double immunofluorescent staining of retinal pieces with $\mathrm{JH} 492$, and the monoclonal S-cone antibody OS-2, was used to confirm that equine cones contain either the $\mathrm{M} / \mathrm{L}$ - or the S-pigment (Fig. $5 A, B)$. We found horse cone densities to range from $\sim 5000 / \mathrm{mm}^{2}$ in peripheral retina to $15,000-20,000 / \mathrm{mm}^{2}$ in the visual streak. The S-cones have a patchy distribution; they are not a regularly spaced subset (Fig. $5 B, C$ ). S-cones constitute a varying proportion of the cones, ranging from $\sim 10 \%$ at the visual streak to $20-25 \%$ in midperipheral and peripheral retina. The constitution of the cones of ass, mule, and zebra retinae is qualitatively similar.

There were three reasons to identify the types of cone contacted by the terminal aggregates of A- and B-type cells as directly as possible. (1) The position of A-type cells in the retina and the appearance of their terminal aggregates indicate that they are horizontal cells, but their unusual morphology made confirmation desirable. Electron microscopy (to show that their terminals form the lateral elements of the cone triads) could not be done because of the insufficient yield of injected cells. Demonstration of apposition between cone pedicles and their terminal aggregates was the best practicable approach to support their recognition as horizontal cells. (2) Because the spacing of the terminal aggregates of A-type cells suggests that they contact cone types selectively, it was important to determine whether that selectivity is of the chromatic type of cone. (3) Although the morphology of equine B-type cells resembles that of other mammalian B-type cells, recent work on the $\mathrm{H} 1$ cells of primates (see Discussion) made it necessary to establish whether equine B-type cells contact $\mathrm{S}$-cones as well as $\mathrm{M} / \mathrm{L}$-cones. To address these issues, LYinjected horizontal cells were reacted with LY antibody to transform the fluorescent dye into a stable DAB reaction product. In this way, stained horizontal cells and their overlying cones could be observed using Nomarski optics. For seven B-type cells and one A-type cell, the tissue was counterstained with an S-cone antiserum.

Figure $5 C$ shows S-cones labeled with JH 455; using Nomarski optics, the unlabeled $\mathrm{M} / \mathrm{L}$-cones can also be observed. The label is strongest in the outer segments, but the rest of the S-cone also labels. Thus, as shown in Figure 6, S-cones (five are designated with arrowheads) can be followed in a focal series to the terminal aggregates of an injected B-type horizontal cell. It is clear from Figure $6 A-D$ that the B-type cell is connected to S-cones. The series also shows that there are many terminal aggregates on the cell that are not synapsing with $\mathrm{S}$-cones. These synapse with $\mathrm{M} / \mathrm{L}$-cones as is demonstrated by Figure 7 . 

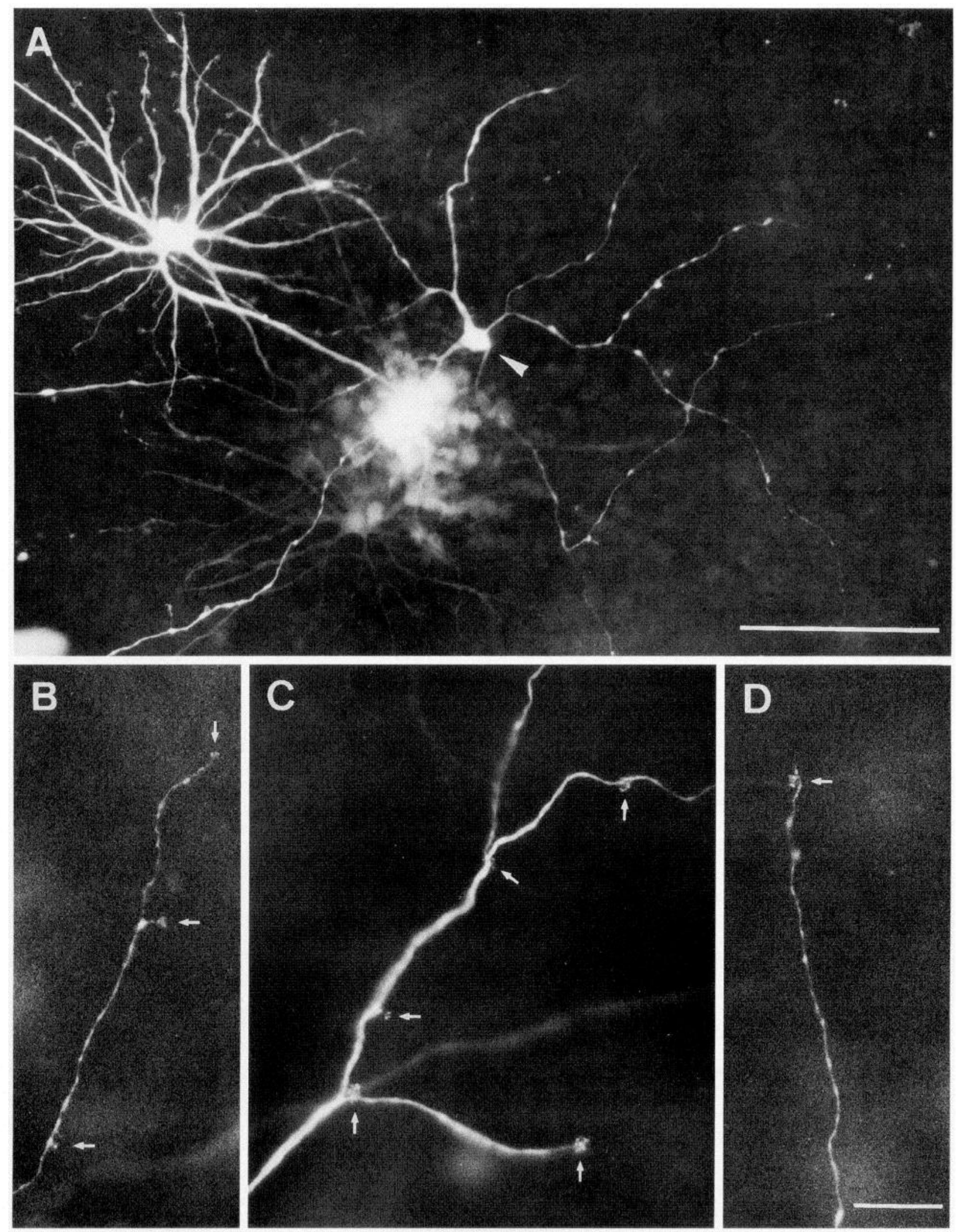

Figure 3. LY-injected A-type cells from peripheral horse retina. A, Low-power view of a large, sparsely branched A-type cell (arrowhead) injected in conjunction with a B-type cell. Dendrites of both cells branch in the same plane. $B-D$, Higher magnification of portions of A-type dendrites to show the wide-spacing of the terminal aggregates (arrows). Compare the terminal aggregate spacing with that of a B-type cell (Fig. $1 B$ ). Scale bars: $A, 100 \mu \mathrm{m} ; B-D$, $20 \mu \mathrm{m}$. 


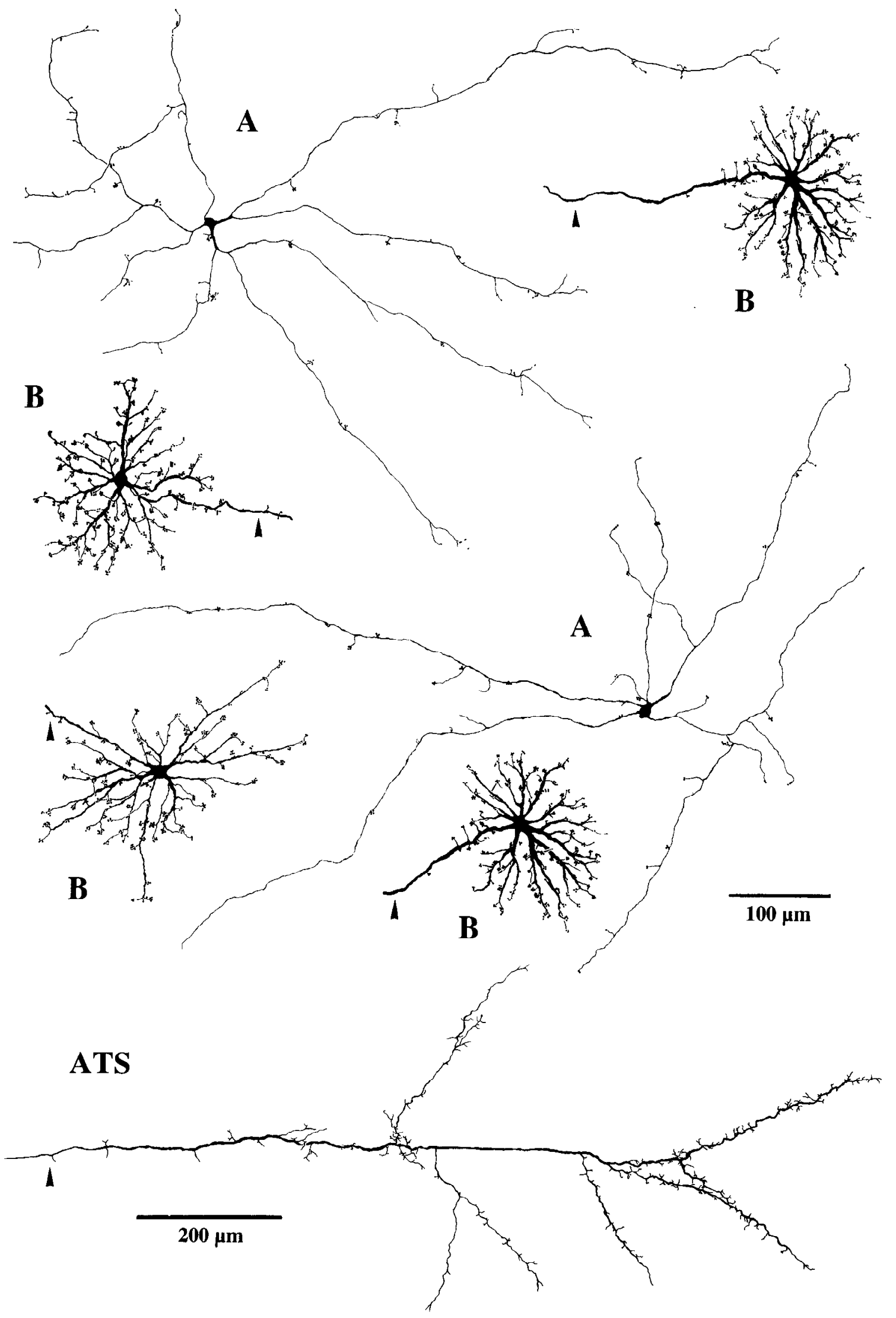

Figure 4. Drawings of LY-injected horse A- and B-type horizontal cells. All dendritic trees are at the same magnification, upper scale bar. The axon terminal system $($ ATS $)$ is at lower magnification, lower scale bar. Axons are marked by arrowheads. All cells are from superior periphery, exccpt for the lower left B-type cell, which is from inferior periphery. 

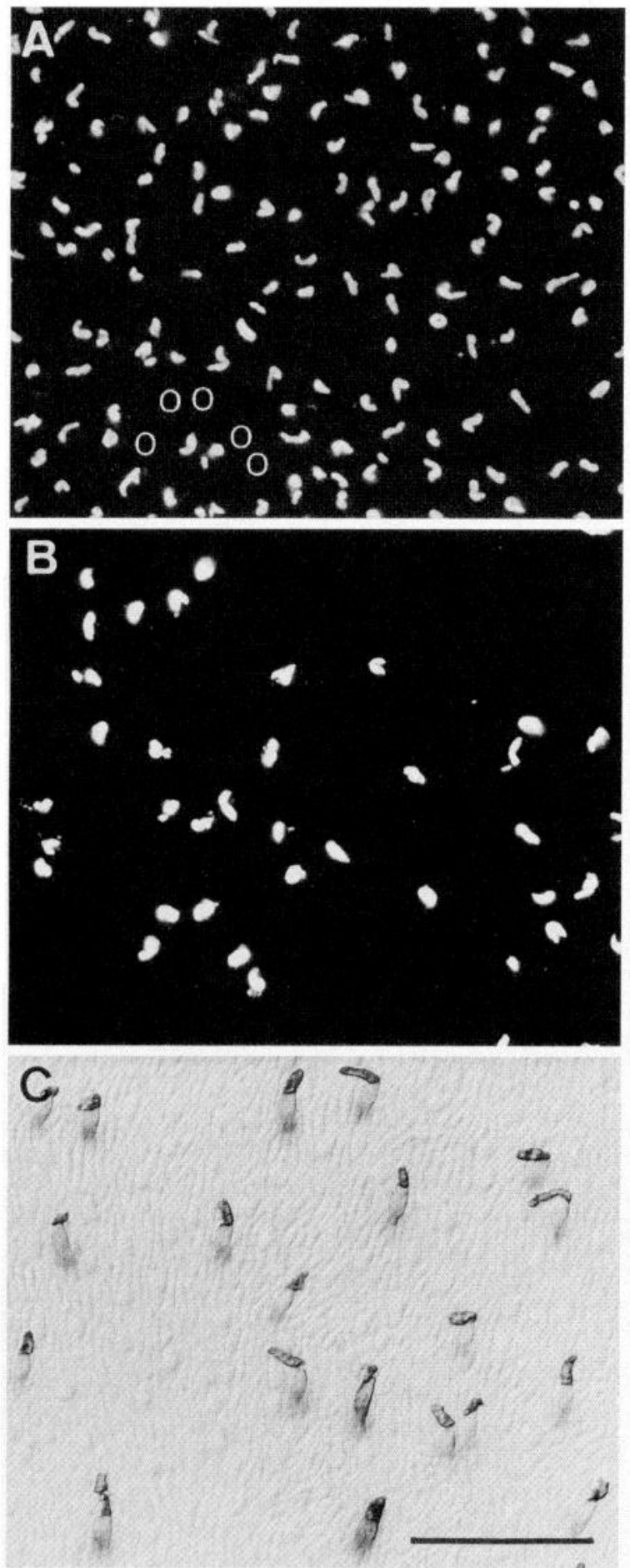

Figure 5. Cone photoreceptor populations in peripheral horse retina. $A$, $B$, Double immunofluorescence with $\mathrm{M} / \mathrm{L}$-cone antiserum $\mathrm{JH} 492$ and S-cone antibody OS-2. A, M/L-cone outer segments visualized with Texas red. The M/L-cones have a rather high density. There are some irregular spaces. $B$, Same field as $A$ showing S-cone outer segments visualized with FITC. The S-cones have a low density and are irregularly distributed. They occupy the spaces in the M/L-cone mosaic. The position of a group of five S-cones in $(B)$ is shown by five open circles in $A$. S-cone outer segments are larger than those of $\mathrm{M} / \mathrm{L}$-cones. In this field, the total cone density is $7500 / \mathrm{mm}^{2}$, of which S-concs arc $20 \%$. C, S-cone pattern in another retina stained by antiserum JH 455 and visualized with DAB. This antiserum also labels the inner segments and somata of S-cones. The Nomarski optics, in addition, reveals the unstained $\mathrm{M} / \mathrm{L}$-cones and the thinner, more numerous rods. Scale bar, $50 \mu \mathrm{m}$.
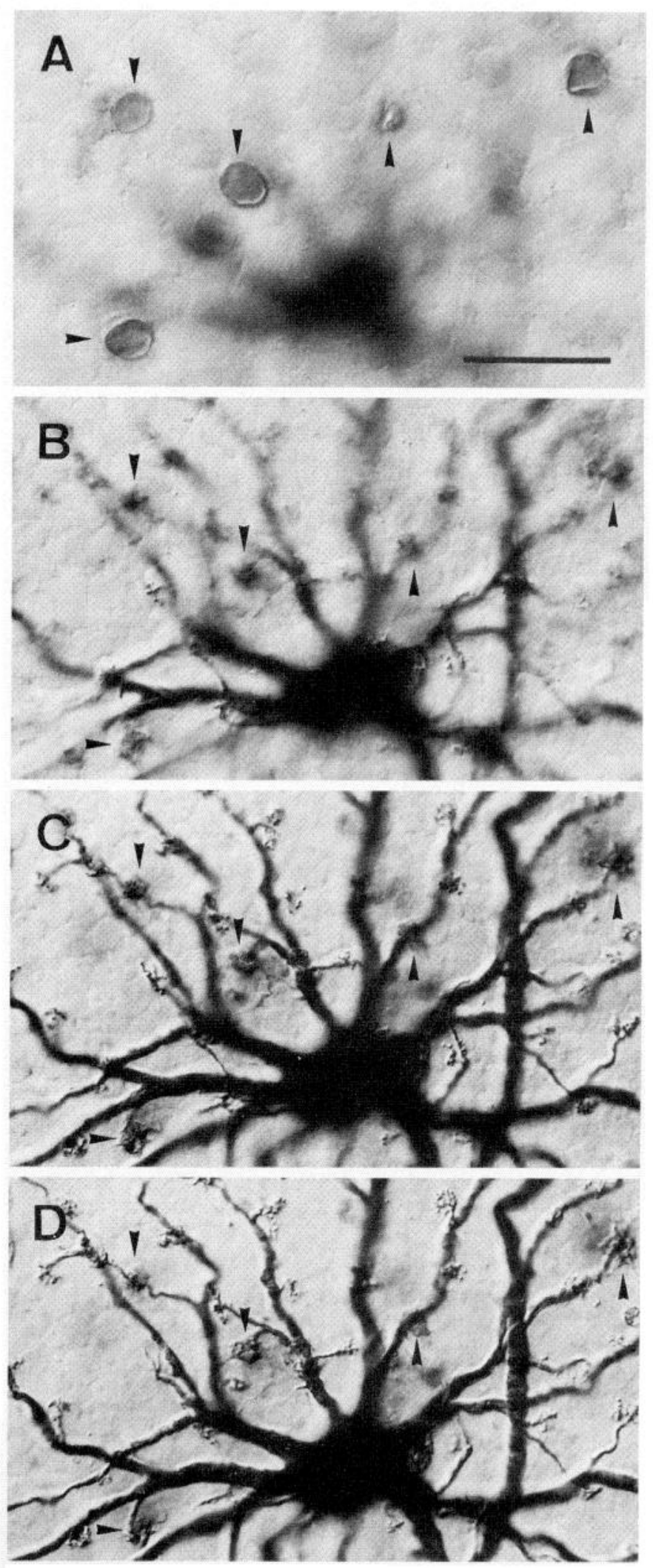

Figure 6. Mule B-type horizontal cell showing S-cone contacts. The LY-injected cell was DAB-labeled with an LY antibody, and the S-cones were simultaneously stained with $\mathrm{JH} 455$. The focal series shows the labeled S-cone somata $(A)$ and their labeled axons $(B)$ in the outer nuclear layer and in the OPL $(C, D)$, where they reach the terminal aggregates on the B-type dendrites. Arrowheads indicate five S-cones throughout the series. Scale bar, $25 \mu \mathrm{m}$. 

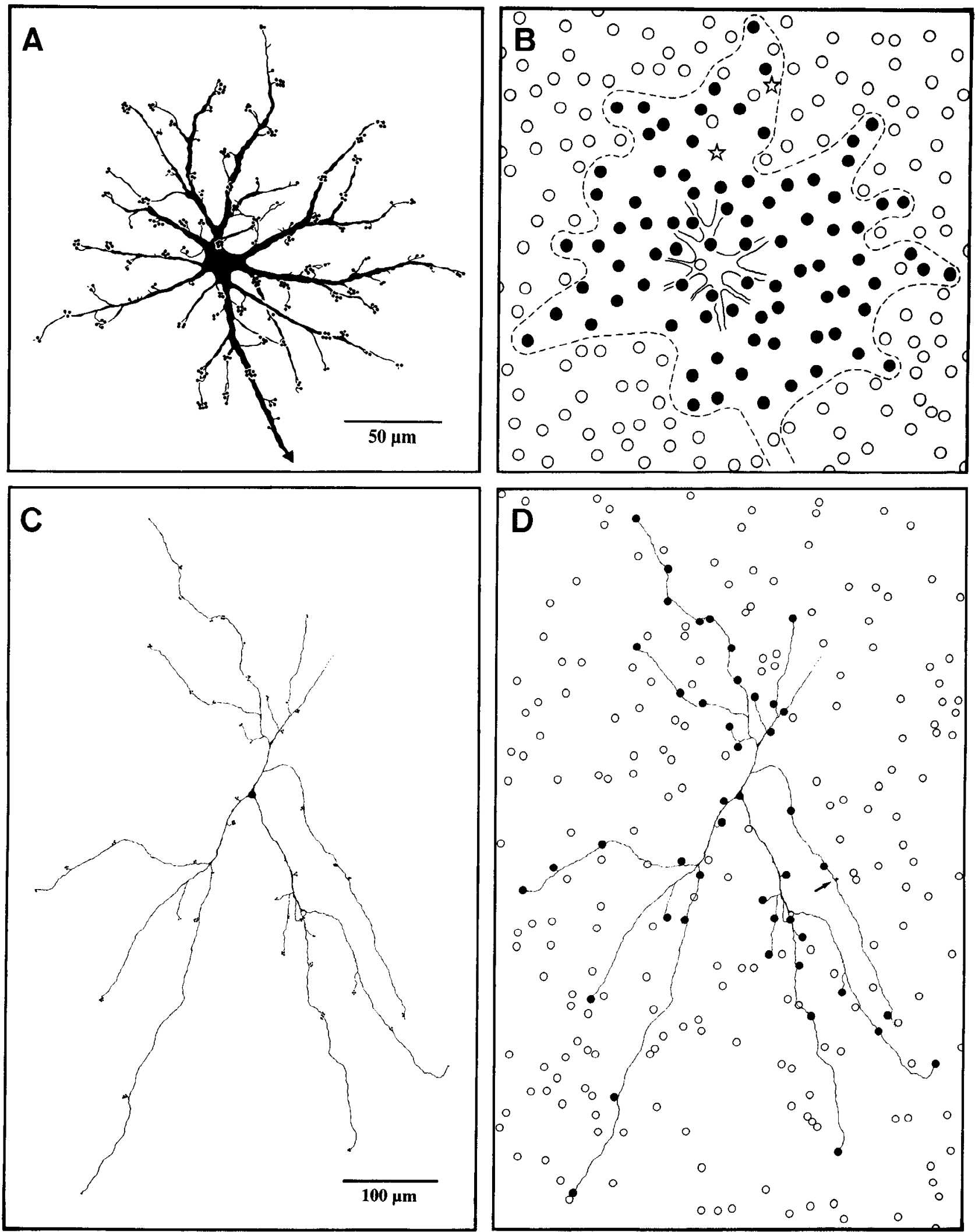

Figure 7. Drawings of LY-injected horse B- and A-type horizontal cells and their overlying cone mosaics. $A$, Cell type $\mathrm{B}$ with its terminal aggregates; axon arrowed. $B$, The circles represent the entire overlying cone mosaic as seen with Nomarski optics. The dendritic field of the B-type cell is circumscribed by a broken line. Filled circles indicate cones congruent with the cell's terminal aggregates; open circles are cones not in contact with this particular B-type cell. Two stars mark the positions of two terminal aggregates on the cell that could not be matched to a cone. $C$, Cell type A with its terminal aggregates. $D$, Same cell as in $C$ with addition of the overlying S-cone mosaic as determined by antiserum labeling. Filled circles indicate S-cones whose pedicles are congruent each with one terminal aggregate of the cell; open circles are S-cones not in contact with the cell. The arrow marks the only terminal aggregate with no matching S-cone. 
Figure 7, $A$ and $B$, shows a diagram of the dendrites of a horse B-type cell together with its overlying cone matrix as seen with Nomarski optics. Within the circumference of the dendritic ficld of this cell, there are 91 cones, of which 84 (92\%; filled circles in Fig. $7 B$ ) were observed to be in register with a terminal aggregate. Seven cones within the dendritic field (including the initial part of the axon) were not contacted by this cell. For two of the cell's terminal aggregates, no corresponding cones could be found (stars in Fig. $7 B$ ), and no congruent cones were found for the two single terminals at the beginning of the axon. Analysis of three further cells showed that, on average, the dendrites of B-type cells contact $\geq 90 \%$ of the cones within their field. It is clear from this and from the observations in Figure 6 that equid B-type cells are contacting both S-cones and $\mathrm{M} / \mathrm{L}$-cones.

The cone connections of the A-type cell are dramatically different. Figure $7 C$ shows an A-typc cell and its terminal aggrcgates. Figure $7 D$ gives the pattern of S-cones overlying this cell. Those $\mathrm{S}$-cones represented by filled circles are in register with the terminal aggregates of the cell. Of 45 terminal aggregates on the cell, only one had no S-cone in its vicinity (arrow in Fig. 7D). This is strong evidence that horse A-type cells selectively contact $\mathrm{S}$-cones. Because the A-type cell branches sparsely, it does not reach all the $\mathrm{S}$-cones within the circumference of its dendritic field, and sometimes S-cones sufficiently close to a dendrite to be accessible are not contacted. But whenever contact with a cone occurs, it is an $\mathrm{S}$-cone. The cell was in the periphery of the retina where the S-cones represented $\sim 20 \%$ of the cone population. For the A-type horizontal cell to be nonselective, only $20 \%$ of its contacts should be with S-cones. The chance that $98 \%$ of the terminal aggregates of the cell in Figure 7, $C$ and $D$, randomly contacted $\mathrm{S}$-cones is negligible. Connections with $\mathrm{M} / \mathrm{L}$-cones cannot absolutely be excluded. It is possible that the unstained peripheral parts of some dendrites carry terminal aggregates contacting $\mathrm{M} / \mathrm{L}$-cones. However, for there to be a significant connectivity with $\mathrm{M} / \mathrm{L}$ cones on the stained part of the dendrites beyond that arrowed in Figure $7 D$, it would have to be assumed that LY diffusion into the cell's terminal aggregates has been selective. This seems very unlikely, and we know of no precedent.

\section{A- and B-type horizontal cell populations}

To quantify A- and B-type horizontal cell populations, we used an antiserum against calbindin (CaBP $28 \mathrm{kDa})$. It is known to stain the horizontal cells of a wide range of mammalian retinae (Röhrenbeck et al., 1987, 1989; Peichl and González-Soriano, 1994). Here we describe the horse in detail but emphasize that ass, mule, and zebra retinae have the same pattern of calbindin staining. Figure $8 A$ shows that the antiserum stains two populations of horizontal cells. The denser population has B-type dendritic trees that cover the outer plexiform layer in a rich plexus. Their axons are part of the plexus but cannot be resolved in the figure. A second population of cells (arrows in Fig. $8 A$ ) is sparser, with soma sizes and thin dendrites that closely match the injected A-type cells. This population is most clearly visible when the immunoreaction is not intensified with nitro blue tetrazolium (Fig. $8 B$ ).

Congruence between the calbindin immunoreactive cells and the A- and B-type horizontal cells as revealed by LY injections is shown in Figure $8, C$ amd $D$. Here a piece of retina, with two LY-injected B-type cells and one A-type cell, has been immunoreacted for calbindin. The injected cells are immunoreactive and are integral to the mosaic of calbindin-reactive cells. This experiment establishes that the calbindin-immunoreactive populations are the A- and B-type horizontal cells observed by LY injection. There was never any indication that calbindin-stained cells in horse retina had proccsses descending to the inner retina. The immunostaining also gave no indication of the presence of a further type of horizontal cell in equid retinae.

Many retinal nerve cells form regular mosaics; the degree of regularity in the tiling of a retina can thus be used as an indicator of the homogeneity of a cell type (Wässle and Riemann, 1978). Figure 9 gives a nearest-neighbor analysis of the spacing of the somata of the B- and A-type mosaics derived from a calbindinreacted retina. Both the B-type and A-type populations have a Gaussian distribution of nearest-neighbor distances, indicating a statistical regularity of spacing of the somata. The degree of regularity is given by the ratio $r$ of the mean distance between the cells over the SD of the histogram. For the field of peripheral retina illustrated in Figure 9, this regularity index $r$ is 8.0 for the B-type mosaic and 3.7 for the A-type mosaic. The nearestneighbor analysis of further fields in midperipheral and central retina yielded ratios of $5.0 \leq r \leq 8.0$ for the B-type mosaics and $3.4 \leq r \leq 3.7$ for the A-type mosaics. There was no consistent dependence on retinal location. Hence, overall the B-type mosaic is more orderly than that of the A-type.

These regularity indices can be compared with those for cat Aand B-type horizontal cells, which are 6.6 and 6.0, respectively (Wässle et al., 1978b), and with those of rodent B-type cell mosaics, which are between 3.8 and 5.1, depending on the species (Peichl and González-Soriano, 1994). The regularity of the mosaics is further evidence that horse A- and B-type cells are two homogeneous and independent populations of horizontal cells. The regularity of the A-type cell spacing is relatively low, but it is significantly different from random (Poissonian curves in Fig. 9; see also the conformity ratio charts in Cook, 1996). The lower regularity of the mosaic of A-type somata may be related to the fact that they are not at the geometric center of the dendritic trees; these may be more regularly tiled than the soma positions predict.

Over the whole extent of the horizontal visual streak, the population density of horse B-type cells as measured in calbindinimmunoreacted retinae is in the range of $500-900 / \mathrm{mm}^{2}$; it may be $>1000 / \mathrm{mm}^{2}$ in the central area at the temporal end of the visual streak, but there the staining was too faint to give a reliable density value. From the streak outward, densities fall off sharply so that over most of the retina B-type cell densities are 100-300/ $\mathrm{mm}^{2}$ (Fig. 10). A-type cells show a similar gradient but are $\sim 10$ times less dense; in the visual streak, their density is $50-100 / \mathrm{mm}^{2}$ and, over the remainder of the retina, $15-45 / \mathrm{mm}^{2}$. The density ratio of B-type to A-type cells varies between 5 and 10 . The variation is not strongly correlated with retinal location; in the visual streak, the ratios are between 7 and 10; elsewhere in the retina they are between 5 and 8 (Fig. 10). In peripheral retina, the coverage factor (dendritic field area $\times$ cell density) for B-type cells is $\sim 5-6$; that is, on average an individual cone pedicle contacts five to six B-type cells. In central retina, our sample of LY-injected B-type cells was too small to make a reliable estimate of their coverage. No attempt was made to estimate the coverage of A-type cells because of the small sample size $(n=6)$ and the possibility that their dendritic fields were not completely filled.

The calbindin immunoreaction also revealed all the cones (as it does, for example, in primate retina) (Röhrenbeck et al., 1989). This enabled a direct comparison of horizontal cell and cone densities. In the periphery, the density ratio of cones to B-type horizontal cells is 37 . By this measure, the density ratio of cones to 

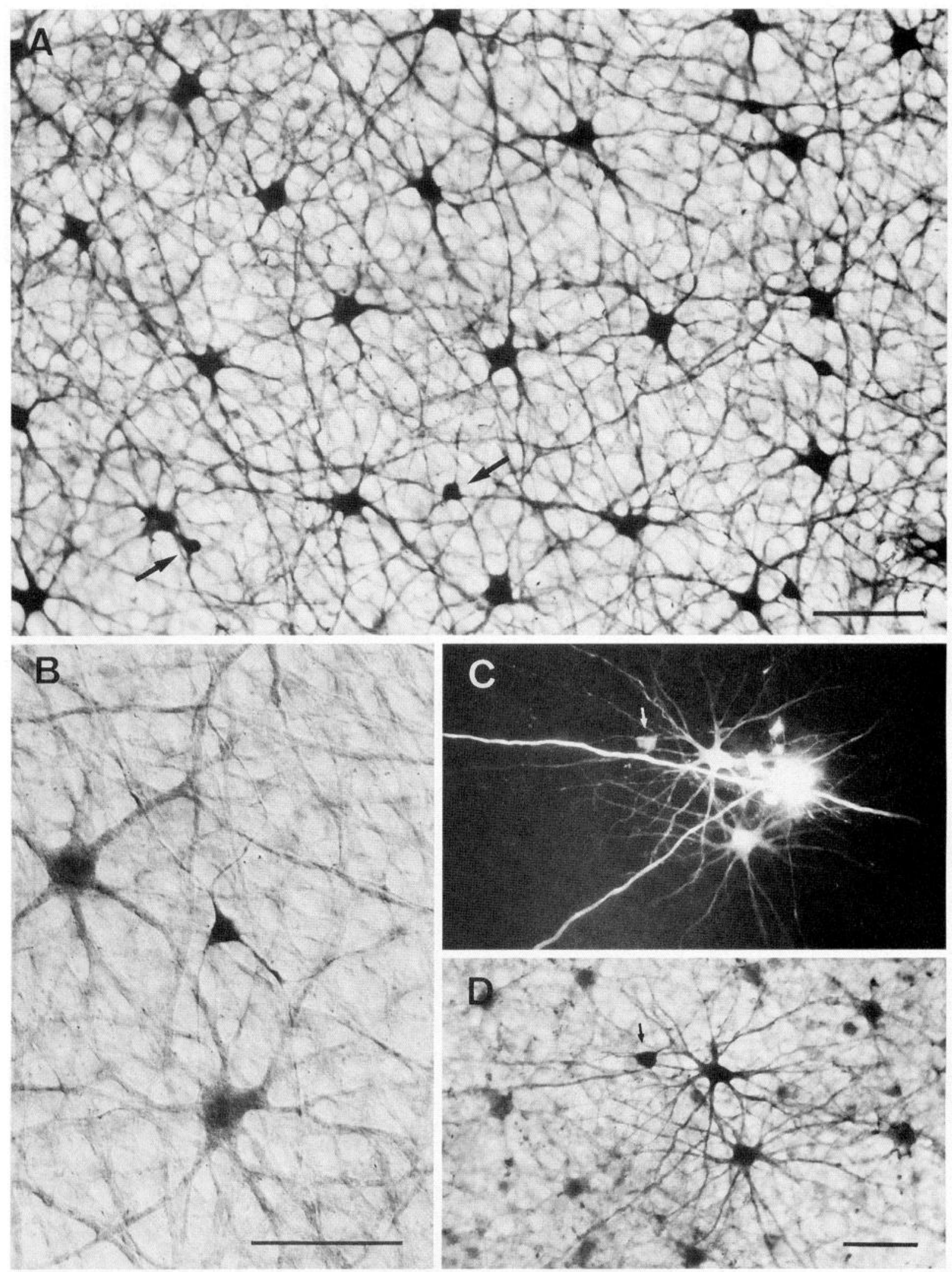

Figure 8. Calbindin-immunostained horse horizontal cells. $A$, Field of peripheral retina where the DAB reaction product was intensified with nitro blue tetrazolium, showing the somata and dense dendritic plexus in the OPL formed by the B- and A-type cells (two of the five A-type cells in the field are marked by arrows). B, Similar field at higher power. Here the unintensified DAB reaction shows the A-type cell more intensely labeled than the B-type cells and reveals more of its sparse dendritic branching. $C$, LY injection of one A-type cell (arrowed) and two B-type cells. $D$, Same field counterstained with calbindin to show the A- and B-type cells are part of the calbindin-labeled population. Scale bars, $50 \mu \mathrm{m}$. 


\begin{tabular}{|c|}
\hline 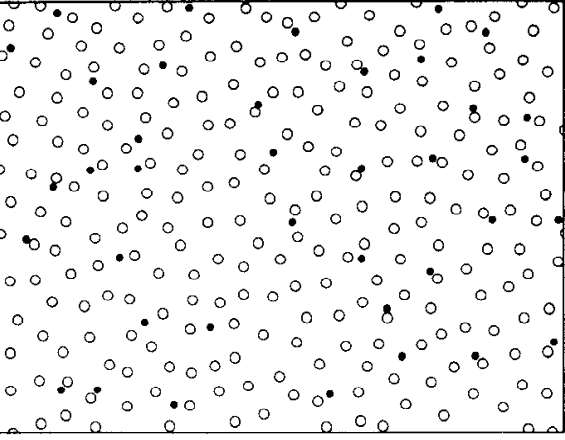 \\
\hline
\end{tabular}

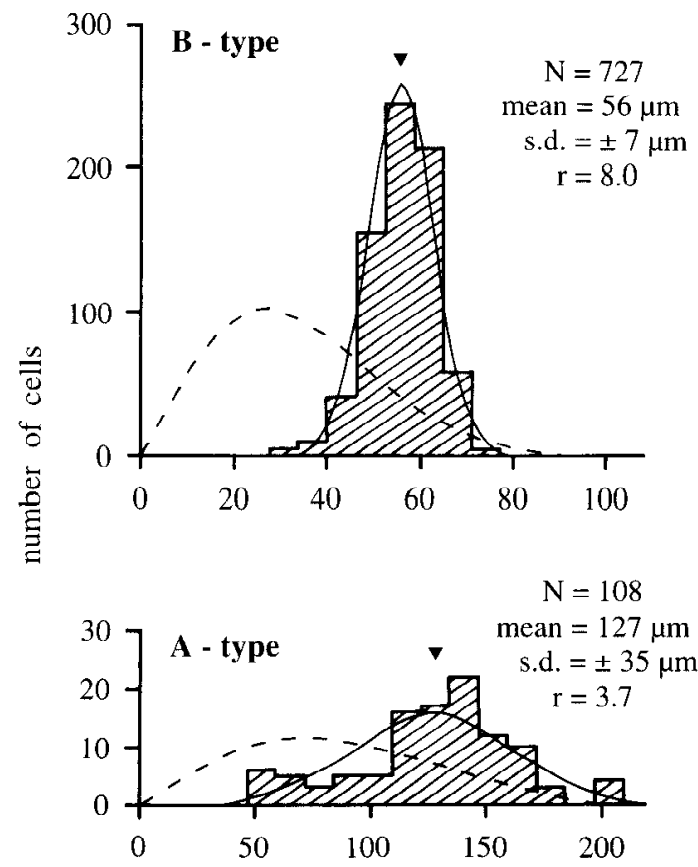

nearest neighbour distance ( $\mu \mathrm{m})$

Figure 9. Analysis of horse horizontal cell mosaics. Top, Mosaic of somata in a field from superior peripheral retina. Open circles are B-type, filled circles A-type cells. The field illustrated is $1200 \times 900 \mu \mathrm{m}$. Bottom Nearest-neighbor distance histograms for the B-type and A-type populations (hatched) in a larger field, including the region illustrated. The histograms are well matched by the Gaussian curves (solid) describing a regular cell distribution with the same mean soma distance and SD but not by the Poissonian curves (broken) describing the nearest-ncighbor distances in a random cell distribution of the same density. The insets give the number of cells in the sample $(N)$, the mean distance (arrowhead in histograms), the $\mathrm{SD}$, and the regularity index $(r)$.

A-type cells is 223. However, they are uniquely connected to $\mathrm{S}$-cones, and that ratio is 33. A-type cells have $\sim 40-60$ terminal aggregates, so they are sufficient to provide all S-cones with contacts, even to the extent that many S-cones can contact more than onc A-type cell.

In some mammalian retinae (e.g., the cat and the rabbit), A-type horizontal cell populations can be stained both by classical neurofibrillar methods and antibodies to neurofilament proteins (for review, see Wässle et al., 1978b; Löhrke et al., 1995); none reacted in this way in equid retinae. Antibody N52 against the heavy subunit of the neurofilament triplet protein (NF-H) stained the B-type cells (Fig. 11A). This was
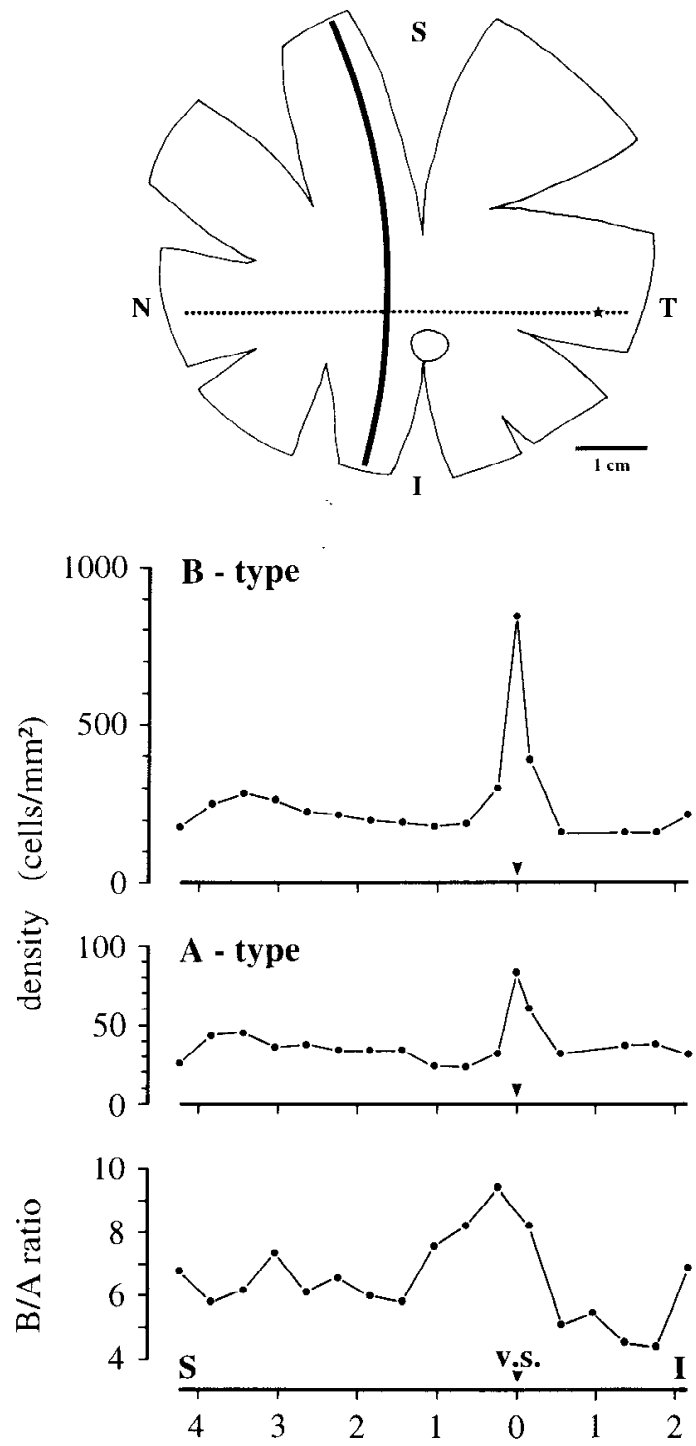

distance from visual streak $(\mathrm{cm})$

Figure 10. Topography of horse horizontal cells. Density distribution of $\mathrm{A}-$ and B-type cells (middle) and corresponding B/A density ratios (bottom) along a superior-inferior transect in nasal retina, marked as a solid line in the schematic retina (top). In the retinal scheme, the visual streak (dotted line), the central area (star), and the optic nerve head (open profile) are also indicated. $S$, Superior; $I$, inferior; $T$, temporal; $N$, nasal.

useful confirmation of the calbindin analysis (compare Figs. 8 and 11); the population of cells revealed is at the same density and regularity. A classical neurofibrillar staining method in the horse only produced very faint staining of B-type cell bodies and dendrites. It did, however, intensely stain a dense plexus of criss-crossing fibers that ran unbranched for long distances through the outer plexiform layer (Fig. 11B). They were confined to this layer. Although they could not be traced to a soma, their diameters and straight-running course over long distances mean that they are the axons of B-type horizontal cells. This confirms that the B-type cell axons are of considerable length. Because the field of peripheral retina shown in Figure $11 B$ contains only $\sim 20$ B-type cell bodies and because each cell has only one axon, the dense plexus observed must include the axons of very distant B-type cells. 

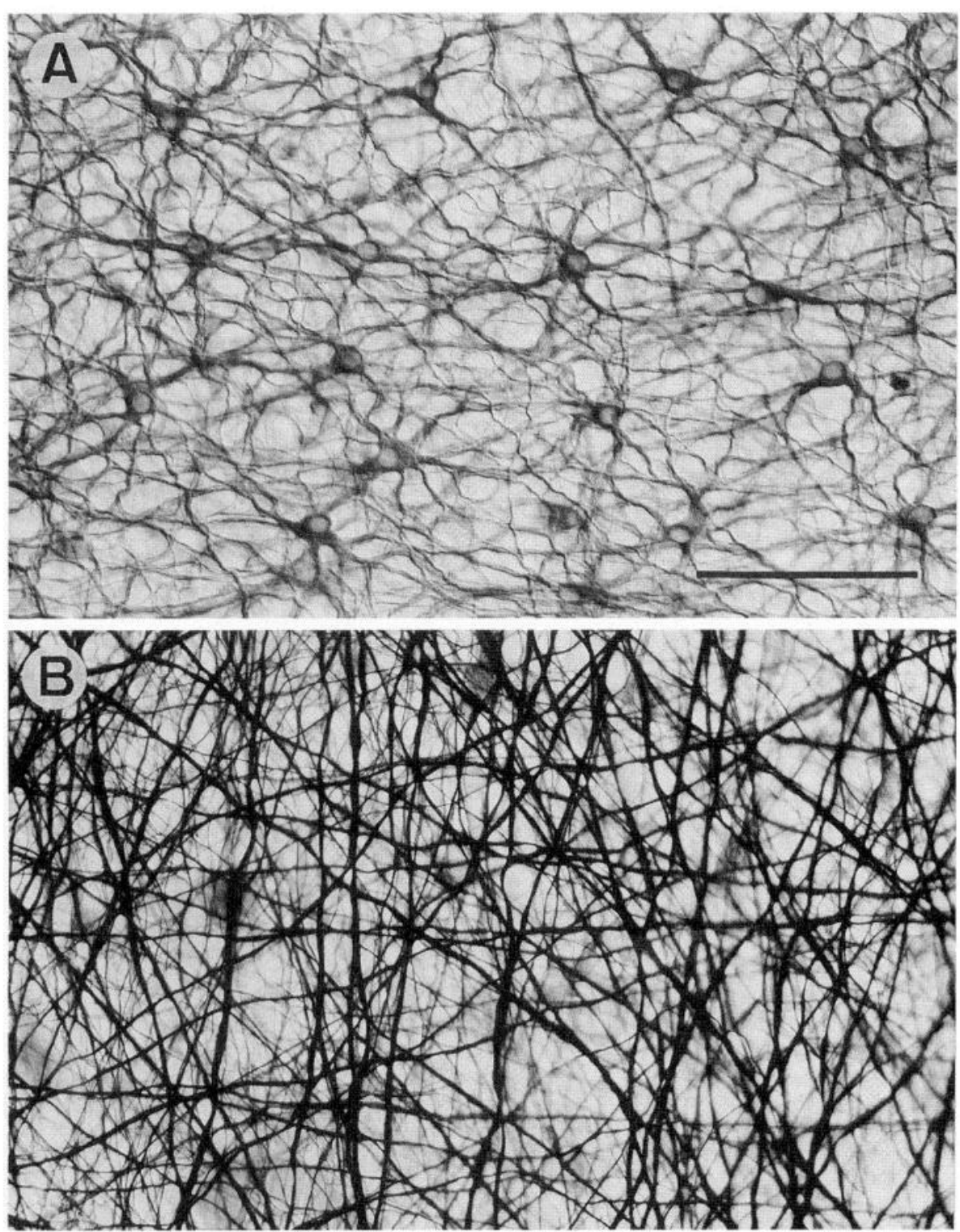

Figure 11. Horse retina. A, Flat view of the OPL stained with $\mathrm{N} 52$ to show the neurofilamentcontaining B-type cell somata and dendrites. $B$, Flat view of the OPL stained with a neurofibrillar method to show the dense plexus of B-type cell axons. The plexus makes the faintly stained B-type somata difficult to see. Scale bar, $100 \mu \mathrm{m}$.

\section{DISCUSSION}

The majority of mammalian retinae that have been examined have two morphological types of horizontal cell (for review, see Ramon y Cajal, 1893; Gallego, 1986; Boycott et al., 1987; Sandmann et al., 1996). Their detailed functional role is poorly understood, and it is not clear why there are two distinctive morphological types. The present observations on equid retinae also demonstrate two kinds of horizontal cell. The equid B-type has some detailed peculiarities (discussed below), but the essential characteristics are those of B-type cells of other mammalian retinae. The second type of equid horizontal cell has the remarkable feature that it synapses directly only with S-cones. For this reason, initially, we referred to the cell as C-type (Peichl et al., 1995), following the precedent set by Famiglietti's (1990) claim for an S-cone-selective (third) type of horizontal cell in the rabbit retina. However, in use, this terminology has led to misunderstandings. As discussed below, present comparative anatomical information favors the interpretation that it is a modified form of the mammalian A-type cell. We have, therefore, retained the A (for axonless) terminology for the second type of horizontal cell in the Equidae.

\section{B-type horizontal cells}

B-type horizontal cells are common to all mammalian retinae, including marsupials (for review, see Callego, 1986; Boycott et al., 1987; Peichl and González-Soriano, 1994; Sandmann et al., 1996). Their defining feature is possession of a single axonal process contacting rods; they are the only horizontal cells directly connected to rods. Their overall morphology is rather similar across species. There is, however, a notable ordinal difference between the dendrites, which are thicker in equid and artiodactyl B-type cells, and thinner in the B-type cells of other mammals, such as the cat and the rabbit (for a fuller discussion, see Sandmann et al., 1996). The dendrites of B-type horizontal cells are generally supposed to make unselective cone contacts (Gallego, 1986; Boycott et al., 1987). This supposition has been primarily inferential, but recently, contact with $\mathrm{S}$ - as well as $\mathrm{M} / \mathrm{L}$-cones has been directly established for the B-type horizontal cell of tree shrew (Müller and Peichl, 1993). We have shown here that equid B-type cells are similarly nonspecific. These two results are important, because it appears (see below) that a large proportion of $\mathrm{H} 1$ (B-type) cells of primates do not directly contact S-cones. 
Equid B-type horizontal cell axons are much longer than in other mammals and end in a characteristically sparse axon terminal system. From the work of Nelson et al. (1975) in cat retina, it is generally assumed that there are no electrical signals along the axon. Thus, the functional significance of the axonal lengths of B-type cells is unclear; they might simply vary with the size of the eye. In those mammals with high rod densities, the axon terminal systems of B-type cells branch densely into fine processes going to the rods. Although equid retinae also have high rod densities (Fig. $5 C$ ), the axon terminal system is sparsely branched (Figs. $1 C, D, 4)$. There is no immediately obvious explanation; however, the density of the axonal plexus (Fig. $11 B$ ) suggests that the population of axon terminal systems provides sufficient overlap to contact all the rods.

\section{A-type horizontal cells}

The equid A-type horizontal cell conforms with those of most mammals by not having an axon; otherwise, it is very different. The dendrites are thin and sparse and branch infrequently (Figs. $3,4)$. The present article has provided a morphological demonstration that the direct cone input is entirely from S-cones. Most mammalian A-type cells contact the vast majority of cones within their dendritic field without regard to cone type (see below). This raises questions as to the comparative anatomical status of equid A-type horizontal cells and serves to highlight some general problems concerning mammalian $\Lambda$-type cells.

In general, nonprimate mammals are dichromats. They have $\mathrm{S}$ (blue)-cones and one type of $\mathrm{M} / \mathrm{L}$-cone, whose exact spectral sensitivity in the red/green range varies according to the species (Jacobs, 1993). Our immunocytochemical data show that the horse has at least two cone types (Fig. 5), and a behavioral study suggests that it is a dichromat (Pick et al., 1994). There is a higher than average percentage of S-cones in the horse retina $(10-25 \%$ compared with the usual mammalian S-cone proportion of 5-10\%). S-cones are considered a phylogenetically ancient population of mammalian cones (Okano et al., 1992; Jacobs, 1993; Bowmaker, 1995). Hence, there could be a blue-cone pathway as distinctive as the rod pathway (for review, see Daw et al., 1990). In monkeys, a "blue-on" opponent pathway through a blue-cone bipolar cell to a distinct bistratified ganglion cell type has been identified (Mariani, 1984a,b; Kouyama and Marshak, 1992; Dacey and Lee, 1994); a possible blue-cone bipolar cell has also been described in the rabbit retina (Famiglietti, 1990). Thus, bccause mammalian horizontal cells serve the rod and cone pathways separately, it can be imagined that the S-cones also have a dedicated horizontal cell.

On the above line of reasoning, the equid A-type cell would be a phylogenetically venerable third type of horizontal cell that has yet to be found in other mammals alongside the A- and B-type cells. This possibility was first raised for the rabbit retina. Rabbit retinae certainly have A- and B-type horizontal cells (Dowling et al., 1966; Dacheux and Raviola, 1982; Kolb and Normann, 1982). Famiglietti (1990) described two Golgi-stained examples of a sparsely branched horizontal cell, with a few groups of terminals scattered along its processes, which suggested cone-selective contacts. He postulated that these were with blue cones and called the cell C-type. This C-type cell has not been seen in calbindin-stained rabbit retinae (Röhrenbeck et al., 1987) or observed during extensive studies in which populations of cells have been dyeinjected (Vaney, 1993; Mills and Massey, 1994). Were Famiglictti's observation confirmed, then the rabbit retina would have three basic types of horizontal cell. That would suggest that the equid $\mathrm{S}$-cone-selective cell is a homolog and, consequently, that an
A-type cell going to all cones had been lost. Although that may seem unlikely, there is an example from rodents. Whereas representative species of several rodent families have A- and B-type cells, some members of the Muridae possess only a B-type cell (Peichl and González-Soriano, 1994). Loss of an A-type cell also could have happened in equids during the evolution of perissodactyls, leaving only $\mathrm{B}$ and $\mathrm{C}$ out of three types of mammalian horizontal cell. Another possibility is to suppose that the B-type cell is conserved in equid retinae, and the S-cone-selective cell is a neomorph evolved as the A-type cell was lost. We know of no precedent for this in retinal studies; it is logical, but unlikely.

The simplest and most likely possibility is to regard the cquid axonless horizontal cell as an A-type cell whose connectivity has evolved to be restricted to direct synapses only with S-cones. In support of this, there is now increasing evidence across the spectrum of mammalian A-type horizontal cells of varied connections and morphology. In cat and rabbit, the A-type cell dendrites are thick relative to those of the B-type cells (Boycott et al., 1978; Dacheux and Raviola, 1982; Kolb and Normann, 1982); in artiodactyls their dendrites are thinner than those of the B-type cells (Sandmann et al., 1996). In tree shrew, A-type cells are very large with an axon-like dendritic branching pattern (Mariani, 1985; Müller and Peichl, 1993). With this variety of overall morphology, the thin dendrites and sparse branching of the equid A-type cells seem to be part of a spectrum of diversity.

Previously it has been supposed from studies of cat, rabbit, guinea pig, and tree shrew A-type horizontal cells that they are nonselective of the cones they contact (Wässle et al., 1978a; Raviola and Dacheux, 1990; Müller and Peichl, 1993; Peichl and González-Soriano, 1994). It now appears there may be a greater diversity of connectivity. I inberg et al. (1996) have recently described an H2 (A-type) horizontal cell in the retina of the Californian ground squirrel that only contacts a small proportion of the cones in its dendritic field. The spacing of the terminal aggregates is similar to that of the S-cones, and the authors discuss that there may be a preferential S-cone contact. Retrospective examination of the homologous $\mathrm{H} 2$ cell of the North American red squirrel (Mariani, 1985, his Fig. 13) shows that this too might be similarly selective. So it may be that an S-cone-connected horizontal cell is not unique to equids.

That the connectivity of the two basic types of horizontal cell may have been malleable during the course of evolution of the mammalian retina is supported by recent studies on primates. These have two types of horizontal cells, termed $\mathrm{H} 1$ and $\mathrm{H} 2$ (the presumed equivalents of B- and A-type horizontal cells, respectively; for review, see Boycott et al., 1987; Sandmann et al., 1996). The $\mathrm{H} 1$ cells are generously connected to M/L-cones but only sparsely connected to S-cones. The majority of the $\mathrm{H} 1$ cells in a macaque monkey and a marmoset do not contact any S-cones at all; those that do innervate the S-cone pedicles do so with fewer terminals than they make with $\mathrm{M} / \mathrm{L}$-cones; in contrast, $\mathrm{H} 2$ cells are always connected to $\mathrm{S}$-cones as well as $\mathrm{M} / \mathrm{L}$-cones, and here the $\mathrm{S}$-cones are innervated with more terminals than M/L-cones (Ahnelt and Kolb, 1994a,b; Chan and Grünert, 1996; Dacey et al., 1996; Goodchild et al., 1996). Recordings from macaquc H1 cclls show strong responses to $\mathrm{M}$ - and L-cone stimuli but no responses to S-cone stimuli; the $\mathrm{H} 2$ cells respond equally well to stimulation of S-, M-, and L-cones (Dacey et al., 1996).

\section{Functional aspects}

If the early connectivity pattern of mammalian A- and B-type horizontal cells was indiscriminate of cone type, then it appears 
that during primate evolution, the balance of connectivity changed for both types of horizontal cell. In equids, the connectivity of the B-type cell has remained nonspecific, but the A-type cell became selective of S-cones. It is not clear what selective advantages for visual processing there may have been for such connectivity to have evolved or how those advantages outweighed presumed disadvantages in losing a nonspecifically connected A-type cell or $\mathrm{H} 1$ cell.

The role of mammalian horizontal cells in color processing remains unknown. Primate horizontal cells are spectrally tuned, but they do not provide color-opponent responses (Dacey et al., 1996). Thus, these authors see no role for horizontal cells in the shaping of color-opponent ganglion cell receptive fields. By extrapolation, presumably equid A-type cells also are luminosity detectors spectrally tuned to short wavelengths. A color-opponent response is not to be expected in a cell that receives exclusive input from S-cones. A contribution to ganglion cell color opponency would also require an output to the $\mathrm{M} / \mathrm{L}$-cone pathway.

An important role is attributed to horizontal cells in spatial processing. They have been shown to contribute to the centersurround balance of concentrically organized ganglion cell receptive fields in rabbit retina (Mangel, 1991). Modeling the functional plexus of A- and B-type horizontal cells in cat retina, Smith (1995) has proposed that two types of horizontal cell with different spatial summation properties (i.e., different receptive field sizes) are necessary to create the assumed receptive field properties of cones and bipolar cells. In equid retinae, the $\mathrm{S}$-cones have contacts with both A- and B-type horizontal cells to shape their receptive fields, but the M/L-cones only contact B-type horizontal cells and thus appear deprived of a feedback that is crucial in Smith's (1995) model. The same applies to all cone types in the murid retinae that have no A-type horizontal cells and to the S-cones of primate retinae, which are largely devoid of $\mathrm{H} 1$ cell contacts; it may also apply to the $\mathrm{M} / \mathrm{L}$-cones in the sciurid retinae if their A-type cells turn out to be S-cone-selective. There certainly remains much more to be learned about the structural detail and functional role of mammalian horizontal cells.

\section{REFERENCES}

Ahnelt P, Kolb H (1994a) Horizontal cells and cone photoreceptors in primate retina: a Golgi-light microscopic study of spectral connectivity. J Comp Neurol 343:387-405.

Ahnelt P, Kolb H (1994b) Horizontal cells and cone photoreceptors in human retina: a Golgi-electron microscopic study of spectral connectivity. J Comp Neurol 343:406-427.

Bowmaker JK (1995) The visual pigments of fish. Prog Ret Eye Res 15:1-31.

Boycott BB, Dowling JE (1969) Organization of the primate retina: light microscopy. Philos Trans R Soc Lond Biol 255:109-184.

Boycott BB, Peichl L, Wässle H (1978) Morphological types of horizontal cell in the retina of the domestic cat. Proc R Soc Lond [Biol] 203:229-245.

Boycott BB, Hopkins JM, Sperling HG (1987) Cone connections of the horizontal cells of the rhesus monkey's retina. Proc R Soc Lond [Biol] 229:345-379.

Chan TL, Grünert U (1996) Horizontal cell connections with the short wavelength sensitive cones in the common marmoset Callithrix jacchus. Proc Aust Neurosci Soc 7:46.

Cook JE (1996) Spatial properties of retinal mosaics: an empirical evaluation of some existing measures. Vis Neurosci 13:15-30.

Dacey DM, Lee BB (1994) The "blue-on" opponent pathway in primate retina originates from a distinct bistratified ganglion cell type. Nature 367:731-735.

Dacey DM, Lee BB, Stafford DK, Pokorny J, Smith VC (1996) Horizontal cells of primate retina: cone specificity without spectral opponency. Science 271:656-659.
Dacheux RF, Raviola E (1982) Horizontal cells in the retina of the rabbit. J Neurosci 2:1486-1493.

Daw NW, Jensen RJ, Brunken WJ (1990) Rod pathways in mammalian retinae. Trends Neurosci 13:110-115.

Dowling JE, Brown JE, Major D (1966) Synapses of horizontal cells in rabbit and cat retinas. Science 153:1639-1641.

Famiglietti EV (1990) A new type of wide-field horizontal cell, presumably linked to blue cones, in rabbit retina. Brain Res 535:174-179.

Gallego A (1976) Comparative study of the horizontal cells in the vertebrate retina: mammals and birds. In: Neural principles in vision (Zettler F, Weiler R, eds), pp 26-62. Berlin: Springer.

Gallego A (1986) Comparative studies on horizontal cells and a note on microglial cells. Prog Ret Res 5:165-206.

Golgi C, Manfredi N (1872) Annotazioni istologiche sulla retina del cavallo. Giornale della $\mathrm{R}$ Accademia di medicina di Torino August 1872. Reprinted in: Camillo Golgi-Opera omnia, Vol 1, pp 71-89. Milano: Ulrico Hoepli Editore libraio della real casa (1903).

Goodchild AK, Chan TL, Grünert U (1996) Horizontal cell connections with short wavelength sensitive cones in macaque monkey retina. Vis Neurosci, in press.

Hebel R (1976) Distribution of retinal ganglion cells in five mammalian species (pig, sheep, ox, horse, dog). Anat Embryol (Berl) 150:45-51.

Jacobs GH (1993) The distribution and nature of colour vision among the mammals. Biol Rev Camb Philos Soc 68:413-471.

Johnson GL (1968) Ophthalmoscopic studies on the eyes of mammals. Philos Trans R Soc Lond Biol 254:207-220.

Kallius E (1894) Untersuchungen über die Netzhaut der Säugetiere Anat Hefte 3:527-582.

Kolb H, Normann RA (1982) A-type horizontal cells of the superior edge of the linear visual streak of the rabbit retina have oriented, elongated dendritic trees. Vision Res 22:905-916.

Kolb H, Mariani A, Gallego A (1980) A second type of horizontal cell in the monkey retina. J Comp Neurol 189:31-44.

Kolmer W (1936) Die Netzhaut (Retina). In: Handbuch der mikroskopischen Anatomie des Menschen (von Möllendorff W, ed), Band: Haut und Sinnesorgane, 2. Teil: Auge, pp 295-466. Berlin: Springer.

Kouyama N, Marshak DW (1992) Bipolar cells specific for blue cones in the macaque retina. J Neurosci 12:1233-1252.

Linberg KA, Suemune S, Fisher SK (1996) The retinal neurons of the California ground squirrel, Spermophilus beecheyi: a Golgi study. J Comp Neurol 365:173-216.

Löhrke S, Brandstätter JH, Boycott BB, Peichl L (1995) Expression of neurofilament proteins by horizontal cells in the rabbit retina varies with retinal location. J Neurocytol 24:283-300.

Mangel SC (1991) Analysis of the horizontal cell contribution to the receptive field surround of ganglion cells in the rabbit retina. J Physiol (Lond) 442:211-234.

Mariani AP (1984a) The neuronal organization of the outer plexiform layer of the primate retina. Int Rev Cytol 86:285-320.

Mariani AP (1984b) Bipolar cells in monkey retina selective for the cones likely to be blue-sensitive. Nature 308:184-186.

Mariani AP (1985) Multiaxonal horizontal cells in the retina of the tree shrew, Tupaia glis. J Comp Neurol 233:553-563.

Mills SL, Massey SC (1994) Distribution and coverage of A- and B-type horizontal cells stained with neurobiotin in the rabbit retina. Vis Neurosci 11:549-560.

Müller B, Peichl L (1993) Horizontal cells in the cone-dominated tree shrew retina: morphology, photoreceptor contacts, and topographical distribution. J Neurosci 13:3628-3646.

Nelson R, von Lützow A, Kolb H, Gouras P (1975) Horizontal cells in cat retina with independent dendritic systems. Science 189:137-139.

Okano T, Kojima D, Fukada Y, Shichida Y, Yoshizawa T (1992) Primary structures of chicken cone visual pigments: vertebrate rhodopsins have evolved out of cone visual pigments. Proc Natl Acad Sci USA 89:5932-5936.

Peichl L, González-Soriano J (1993) Unexpected presence of neurofilaments in axon-bearing horizontal cells of the mammalian retina. J Neurosci 13:4091-4100.

Peichl L, González-Soriano J (1994) Morphological types of horizontal cell in rodent retinae: a comparison of rat, mouse, gerbil, and guinea pig. Vis Neurosci 11:501-517.

Peichl L, Ott H, Boycott BB (1987) Alpha ganglion cells in mammalian retinae. Proc R Soc Lond [Biol] 231:169-197.

Peichl L, Sandmann D, Boycott BB (1995) A possible blue cone selective horizontal cell in the horse retina. Soc Neurosci Abstr 21:510. 
Pick DF, Lovell G, Brown S, Dail D (1994) Equine color perception revisited. Appl Anim Behav Sci 42:61-65.

Pinol MR, Kägi U, Heizmann CW, Vogel B, Séquier J-M, Haas W, Hunziker W (1990) Poly- and monoclonal antibodies against recombinant rat brain calbindin- $\mathrm{D}_{28 \mathrm{~K}}$ were produced to map its selective distribution in the central nervous system. J Neurochem 54:1827-1833.

Ramón y Cajal S (1893) La rétine des vertébrés. La Cellule 9:119-257.

Raviola E, Dacheux RF (1990) Axonless horizontal cells of the rabbit retina: synaptic connections and origin of the rod aftereffect. J Neuro cytol 19:731-736.

Rivolta S (1871) Dello strato di cellule moltipolari che formano lo strato intergranuloso od intermedio (Zwischenkörnerlage) nella retina del Cavallo. Giornale di anatomia fisiologia e patologia degli animali (Pisa) 3:185-201.

Röhrenbeck J, Wässle H, Heizmann CW (1987) Immunocytochemical labelling of horizontal cells in mammalian retina using antibodics against calcium-binding proteins. Neurosci Lett 77:255-260.

Röhrenbeck J, Wässle H, Boycott BB (1989) Horizontal cells in monkey retina: immunocytochemical staining with antibodies against calcium binding proteins. Eur J Neurosci 1:407-420.

Sandmann D, Boycott BB, Peichl L (1996) The horizontal cells of artiodactyl retinae: a comparison with Cajal's descriptions. Vis Neurosci, in press.

Schnitzer J (1988) Astrocytes in the guinea pig, horse, and monkey retina: their occurrence coincides with the presence of blood vesscls. Glia 1:74-89.
Smith RG (1995) Simulation of an anatomically defined local circuit: the cone-horizontal cell network in cat retina. Vis Neurosci 12:545-561.

Szél Á, Takács L, Monostori É, Diamantstein T, Vigh-Teichmann I, Röhlich P (1986) Monoclonal antibody recognizing cone visual pigment. Exp Eye Res 43:871-883.

Tauchi M, Masland RH (1984) The shape and arrangement of the cholinergic ncurons in the rabbit retina. Proc $\mathrm{R}$ Soc Lond [Biol] 223:101-119.

Vaney DI (1992) Photochromic intensification of diaminobenzidine reaction product in the presence of tetrazolium salts: applications for intracellular labelling and immunohistochemistry. J Neurosci Methods 44:217-223.

Vaney DI (1993) The coupling pattern of axon-bearing horizontal cells in the mammalian retina. Proc R Soc Lond [Biol] 252:93-101.

Vogt H (1902) Ueber Neurofibrillen in Nervenzellen und Nervenfasern der Retina. Monatsschr Psychiatr Neurol 11:167-181.

Wang Y, Macke JP, Merbs SL, Zack DJ, Klaunberg B, Bennet J, Gearhart J, Nathans J (1992) A locus control region adjacent to the human red and green visual pigment genes. Neuron 9:429-440.

Wässle H, Riemann HJ (1978) The mosaic of nerve cells in the mammalian retina. Proc R Soc Lond [Biol] 200:441-461.

Wässle H, Boycott BB, Peichl L (1978a) Receptor contacts of horizontal cells in the retina of the domestic cat. Proc R Soc Lond [Biol] 203:247-267.

Wässle H, Peichl L, Boycott BB (1978b) Topography of horizontal cells in the retina of the domestic cat. Proc R Soc Lond [Biol] 203:269-291. 